University of Nebraska - Lincoln

DigitalCommons@University of Nebraska - Lincoln

Agronomy \& Horticulture -- Faculty Publications

Agronomy and Horticulture Department

$1-2003$

\title{
Greenhouse Gas Emissions and Soil Indicators Four Years after Manure and Compost Applications
}

\author{
Daniel Ginting \\ University of Nebraska-Lincoln, dginting3@unl.edu \\ Anabayan Kessavalou \\ University of Nebraska-Lincoln \\ Bahman Eghball \\ USDA-ARS, beghball1@unl.edu
}

John W. Doran

Follow this and additional works at: https://digitalcommons.unl.edu/agronomyfacpub

Part of the Agricultural Science Commons, Agriculture Commons, Agronomy and Crop Sciences Commons, Botany Commons, Horticulture Commons, Other Plant Sciences Commons, and the Plant Biology Commons

Ginting, Daniel; Kessavalou, Anabayan; Eghball, Bahman; and Doran, John W., "Greenhouse Gas Emissions and Soil Indicators Four Years after Manure and Compost Applications" (2003). Agronomy \& Horticulture -- Faculty Publications. 1073.

https://digitalcommons.unl.edu/agronomyfacpub/1073

This Article is brought to you for free and open access by the Agronomy and Horticulture Department at DigitalCommons@University of Nebraska - Lincoln. It has been accepted for inclusion in Agronomy \& Horticulture -Faculty Publications by an authorized administrator of DigitalCommons@University of Nebraska - Lincoln. 


\title{
Greenhouse Gas Emissions and Soil Indicators Four Years after Manure and Compost Applications
}

\author{
Daniel Ginting, Anabayan Kessavalou, Bahman Eghball,* and John W. Doran
}

\begin{abstract}
Understanding how carbon, nitrogen, and key soil attributes affect gas emissions from soil is crucial for alleviating their undesirable residual effects that can linger for years after termination of manure and compost applications. This study was conducted to evaluate the emission of soil $\mathrm{CO}_{2}, \mathrm{~N}_{2} \mathrm{O}$, and $\mathrm{CH}_{4}$ and soil $\mathrm{C}$ and $\mathrm{N}$ indicators four years after manure and compost application had stopped. Experimental plots were treated with annual synthetic $\mathbf{N}$ fertilizer (FRT), annual and biennial manure (MN1 and MN2, respectively), and compost (CP1 and CP2, respectively) from 1992 to 1995 based on removal of $151 \mathrm{~kg} \mathrm{~N}$ $\mathrm{ha}^{-1} \mathrm{yr}^{-1}$ by continuous corn (Zea mays L.). The control (CTL) plots received no input. After 1995, only the FRT plots received $\mathrm{N}$ fertilizer in the spring of 1999. In 1999, the emissions of $\mathrm{CO}_{2}$ were similar between control and other treatments. The average annual carbon input in the CTL and FRT plots were similar to soil $\mathrm{CO}_{2}-\mathrm{C}$ emission $(4.4$ and 5.1 $\mathrm{Mg} \mathrm{C} \mathrm{ha}^{-1} \mathrm{yr}^{-1}$, respectively). Manure and compost resulted in positive $\mathrm{C}$ and $\mathrm{N}$ balances in the soil four years after application. Fluxes of $\mathrm{CH}_{4}-\mathrm{C}$ and $\mathrm{N}_{2} \mathrm{O}-\mathrm{N}$ were nearly zero, which indicated that the residual effects of manure and compost four years after application had no negative influence on soil $\mathrm{C}$ and $\mathrm{N}$ storage and global warming. Residual effects of compost and manure resulted in 20 to $40 \%$ higher soil microbial biomass $\mathrm{C}, \mathbf{4 2}$ to $\mathbf{7 4} \%$ higher potentially mineralizable $\mathrm{N}$, and 0.5 unit higher $\mathrm{pH}$ compared with the FRT treatment. Residual effects of manure and compost on $\mathrm{CO}_{2}, \mathrm{~N}_{2} \mathrm{O}$, and $\mathrm{CH}_{4}$ emissions were minimal and their benefits on soil $\mathrm{C}$ and $\mathrm{N}$ indicators were more favorable than that of $\mathbf{N}$ fertilizer.
\end{abstract}

$\mathrm{C}$ OMPOSTED AND NONCOMPOSTED MANURE have long been used as sources of plant nutrients, especially $\mathrm{N}$ and $\mathrm{P}$, to supplement or replace synthetic fertilizers. Besides its nutrient values, manure can increase soil organic $\mathrm{C}$, the most important soil quality and productivity indicator (Larson and Pierce, 1991), and thus enhance desirable soil properties (Sweeten and Mathers, 1985; Sommerfeldt and Chang, 1985). Manure can also be a source of environmental pollution if improperly used. Elevated $\mathrm{P}$ and $\mathrm{N}$ levels in soil increase concerns over water and air quality. When soil with an elevated $\mathrm{P}$ level is carried by runoff to streams and lakes, it can cause eutrophication and algal blooms (Lee et al., 1978, Sharpley et al., 1996). Manure application resulted in greater $\mathrm{P}$ leaching in the soil than similar loading of $\mathrm{P}$ fertilizer (Eghball et al., 1996). High chemical oxygen demand of carbon-enriched runoff sediment (Ginting et al., 2000) can deplete dissolved oxygen in water bodies, thus affecting the quality of aquatic life.

Soil management and organic amendments, such as animal manure and compost, can affect soil organic $\mathrm{C}$

Department of Agronomy and Horticulture and USDA-ARS, University of Nebraska-Lincoln, Lincoln, NE 68583. Joint contribution of USDA-ARS and Univ. Nebraska. Agric. Res. Div., Lincoln, NE, as Paper no. 13722. Received 13 Mar. 2002. *Corresponding author (beghball1@unl.edu).

Published in J. Environ. Qual. 32:23-32 (2003). pools, soil nutrients, and microbial environments and activities, which are some of the controlling factors in the emission of $\mathrm{CO}_{2}, \mathrm{~N}_{2} \mathrm{O}$, and $\mathrm{CH}_{4}$ to the atmosphere (Intergovernmental Panel on Climate Change, 1996; Conrad, 1996). At the end of a 10-yr experiment, application of cattle manure and red clover (Trifolium pratense L.) hay resulted in accumulation of the most labile and biologically active soil organic $\mathrm{C}$ pools (Wander et al., 1994; Wander and Traina, 1996). Biologically active C promotes microbial activities and $\mathrm{CO}_{2}$ emissions from soils. Emission of $\mathrm{N}_{2} \mathrm{O}$ depends on the form of $\mathrm{N}$ found in manure (Intergovernmental Panel on Climate Change, 1996) and rate of manure application. Lessard et al. (1996) reported that total $\mathrm{N}_{2} \mathrm{O}$ emission from soil over a $185-\mathrm{d}$ period increased from 0.7 to $1.0 \mathrm{~kg} \mathrm{~N}_{2} \mathrm{O}-\mathrm{N} \mathrm{ha}^{-1}$ when dairy cow manure application was increased from 170 to $339 \mathrm{~kg}$ total $\mathrm{N} \mathrm{ha}^{-1}$. Agronomic practices in general reduce $\mathrm{CH}_{4}$ oxidation capacity of soils (Mosier et al., 1991; Kessavalou et al., 1998). In northeastern Colorado, $\mathrm{CH}_{4}$ oxidation capacities of tilled and irrigated soils cropped to winter wheat (Triticum aestivum L.) and corn were $90 \%$ lower than grassland soils (Bronson et al., 1992; Bronson and Mosier, 1993).

Continued elevated emissions of greenhouse gases after termination of manure application to soil not only poses a threat of increased atmospheric concentration of greenhouse gases but also increased risk of soil $\mathrm{C}$ and $\mathrm{N}$ depletion. In the long run, this could lead to the deterioration of soil health previously derived from manure application. For most reported research, measurements of greenhouse gas emissions were made within a year of organic material amendment. Little is known about biological and chemical processes occurring in soils several years after the termination of organic amendment. No literature (using the $\mathrm{CAB}$ abstracts database) was found to evaluate both greenhouse gas emission and soil attributes four years after manure or compost application terminated. One relevant study was reported by Wagner-Riddle et al. (1997), who evaluated only $\mathrm{N}_{2} \mathrm{O}$ emission continuously within two years after manure application without evaluation of key soil attributes. A thorough knowledge of the residual effects of manure application on fluxes of greenhouse gases and key soil attributes may provide valuable information for developing efficient manure management practices for crop production.

The objective of this study was to evaluate the residual effects of manure, compost, and $\mathrm{N}$ fertilizer on fluxes of soil $\mathrm{CO}_{2}, \mathrm{~N}_{2} \mathrm{O}$, and $\mathrm{CH}_{4}$, and on soil $\mathrm{C}$ and $\mathrm{N}$ indicators four years after manure and compost application had stopped.

Abbreviations: CP1, compost applied every year; CP2, compost applied every other year; CTL, control; EC, electrical conductivity; FRT, synthetic $\mathrm{N}$ fertilizer; MBC, microbial biomass carbon; MN1, manure applied every year; MN2, manure applied every other year; PMN, potentially mineralizable nitrogen; WFP, water-filled porosity. 
Table 1. The least-square means of cumulative 7-yr carbon input into soils from continuous corn (1992-1998) receiving manure or compost (1992-1995).

\begin{tabular}{|c|c|c|c|c|c|c|c|}
\hline \multirow[b]{2}{*}{ Treatment $\dagger$} & \multicolumn{5}{|c|}{ Plant materials } & \multirow[b]{2}{*}{ Manure } & \multirow[b]{2}{*}{ Total } \\
\hline & Stover & Root & Rhizodeposit§ & Weeds I & Total & & \\
\hline & & & & $C \mathbf{h a}^{-1}$ & & & \\
\hline CTL & 12.1b\# & 6.43 & 9.7 & 0.92 & 29.2 & 0 & 29.2 \\
\hline FRT & $14.4 \mathrm{a}$ & 7.53 & 11.3 & 1.10 & 34.4 & 0 & 34.4 \\
\hline MN1 & 13.8a & 7.22 & 10.8 & 1.05 & 32.8 & 11.5 & 44.3 \\
\hline MN2 & 14.1a & 7.44 & 11.2 & 1.08 & 33.8 & 16.0 & 49.8 \\
\hline CP1 & 13.7a & 7.23 & 10.9 & 1.05 & 32.8 & 11.9 & 44.7 \\
\hline CP2 & $13.5 \mathrm{a}$ & 7.10 & 10.7 & 1.03 & 32.2 & 12.1 & 44.3 \\
\hline
\end{tabular}

† CTL, control; FRT, synthetic N fertilizer; MN1, manure applied annually; MN2, manure applied biennially; CP1, compost applied annually; CP2, compost applied biennially.

$¥$ Root $C$ contributions after harvest are based on shoot to root ratio of 1.18 and root $C$ content of $26.1 \%$ (Buyanovsky and Wagner, 1997).

$\$$ Rhizodeposit (to include root turnover, slough, and exudates) is estimated at $150 \%$ of the root $C$ (Lucas and Vitosh, 1978).

II Due to good weed control, weed $\mathrm{C}$ contribution is based on $5 \%$ of root and stover $\mathrm{C}$.

\# The means followed by different letter are significantly different at $\boldsymbol{P}=\mathbf{0 . 0 5}$. The standard error of differences of means of stover $\mathrm{C}$ is $0.57 \mathrm{Mg}^{-1}$.

\section{MATERIALS AND METHODS}

\section{Site Description}

Experimental plots were established in 1992 at the Agricultural Research and Development Center, Mead, Nebraska $\left(96^{\circ} 30^{\prime} \mathrm{W}, 41^{\circ} 14^{\prime} \mathrm{N}\right)$ to evaluate the effects of manure, compost, and ammonium nitrate $\mathrm{N}$ application on corn production and soil P level. Plots were $12 \mathrm{~m}$ long and $4.6 \mathrm{~m}$ wide (six corn rows), arranged in a randomized complete block design with four replications. Experimental details are given by Eghball and Power (1999) and the selected treatments are briefly described here. The selected treatments were untreated control (CTL), annual $\mathrm{N}$ fertilizer (FRT) as ammonium nitrate and diammonium phosphate, and annual and biennial application of manure (MN1 and MN2, respectively) and compost (CP1 and CP2, respectively).

\section{Total Carbon and Total Nitrogen Inputs}

Treatments were applied in autumn from 1992 to 1995 for the cropping seasons of 1993 to 1996 . The rates of beef cattle manure, composted feedlot manure, and $\mathrm{N}$ fertilizer were based on a need by corn for $151 \mathrm{~kg} \mathrm{~N} \mathrm{ha}^{-1} \mathrm{yr}^{-1}$ to achieve an expected yield level of $9.4 \mathrm{Mg} \mathrm{ha}^{-1}$. The application rates were based on assumption that $40,20,10$, and $5 \%$ of total $\mathrm{N}$ in manure and $20,20,10$, and $5 \%$ of total $\mathrm{N}$ in compost will be plant

Table 2. The least-square means of cumulative 7-yr total nitrogen (TN) removed by grain, TN input as ammonium nitrate (19921995, and 1999) and manure or compost (1992-1995), and plant material TN recycled into soils from continuous corn (19921998).

\begin{tabular}{|c|c|c|c|c|}
\hline \multirow[b]{2}{*}{ Treatment $\uparrow$} & \multirow{2}{*}{$\begin{array}{l}\text { Grain total } \\
\mathbf{N} \text { removed }\end{array}$} & \multirow{2}{*}{$\begin{array}{l}\text { Total } \mathrm{N} \text { input as } \\
\text { fertilizer, compost, } \\
\text { and/or manure }\end{array}$} & \multicolumn{2}{|c|}{$\begin{array}{l}\text { Plant material } \\
\text { total N recycled }\end{array}$} \\
\hline & & & Stover & Root: \\
\hline & & $-\operatorname{kg~N} \mathbf{h a}^{-1}$ & & \\
\hline CTL & $432 c \S$ & 0 & $136 c \S$ & 102 \\
\hline FRT & $704 a$ & 751 & $227 \mathrm{a}$ & 116 \\
\hline MN1 & $633 \mathrm{~b}$ & 945 & $189 b$ & 112 \\
\hline MN2 & 680ab & 1323 & $219 a$ & 114 \\
\hline CP1 & $619 b$ & 1228 & $188 b$ & 113 \\
\hline CP2 & $625 \mathrm{~b}$ & 1323 & $186 \mathrm{~b}$ & 111 \\
\hline
\end{tabular}

CTL, control; FRT, synthetic N fertilizer; MN1, manure applied annually; MN2, manure applied biennially; CP1, compost applied annually; CP2, compost applied biennially.

$\$$ Root TN contributions after harvest are based on root $C$ and root $C$ to $N$ ratio of 66:1 (Hetier et al., 1986). The $C$ to $N$ ratio is similar to the median of the $C$ to $N$ ratio of stover data in our study (67:1).

$\S$ The means followed by different letter are significantly different at $\boldsymbol{P}=$ 0.05 . The standard error of difference of grain TN and stover TN is 29 and $11 \mathrm{~kg} \mathrm{ha}^{-1}$, respectively. available in the first, second, third, and fourth year after application. Detailed characteristics of manure and compost and application rates were presented by Eghball and Power (1999). Total $\mathrm{C}$ and total $\mathrm{N}$ (corrected for ammonium loss during drying) of manure and compost were determined on air-dried samples based on the method described by Schepers et al. (1989). More than 11.5 $\mathrm{Mg} \mathrm{Cha}^{-1}$ (Table 1) and $900 \mathrm{~kg} \mathrm{~N} \mathrm{ha}^{-1}$ (Table 2) were added to the soil by 4-yr (1992-1995) manure or compost application. Manure or compost was applied by hand in late autumn after corn harvest, followed by disking within two days after application. Every year all plots were disked in the spring before corn planting. Plant residue incorporated into the soil was estimated to be 90 to $95 \%$ after spring disking.

Since autumn 1996, the plots were planted to corn each year without any treatment except for FRT plot, where $151 \mathrm{~kg}$ $\mathrm{ha}^{-1} \mathrm{NH}_{4} \mathrm{NO}_{3}-\mathrm{N}$ was applied on 24 Apr. 1999. The plantbiomass $\mathrm{C}$ and $\mathrm{N}$ incorporated into the soil from 1992 to 1999 are given in Tables 1 and 2. Stover biomass was measured after hand harvesting of corn ears from the 6-m corn row (76-cm row width). Stover was chopped and weighed, and then samples were collected for moisture, total $\mathrm{C}$, and total $\mathrm{N}$ measurements. Total $\mathrm{C}$ and total $\mathrm{N}$ of dried stover and grain were determined based on the method of Schepers et al. (1989).

\section{Soil and Temperature Measurements}

Soils were analyzed for bulk density, volumetric water content, electrical conductivity $\left(\mathrm{EC}_{1: 1}\right)$, and $\mathrm{pH}_{1: 1}$ (where the subscript 1:1 indicates soil weight to water ratio). Soil EC and $\mathrm{pH}$ were measured according to the procedure of Smith and Doran (1996). Soil water-filled porosity (WFP) was calculated as the ratio of volumetric water content to soil total porosity. Assumptions for particle density and density of water are 2.65 and $1.0 \mathrm{Mg} \mathrm{m}^{-3}$, respectively. Potentially mineralizable nitrogen (PMN), microbial biomass carbon (MBC), and $\mathrm{NO}_{3}-\mathrm{N}$ were determined after corn harvest on 8 Sept. 1999. The PMN and $\mathrm{MBC}$ were measured with the anaerobic incubation method as described by Gajda et al. (2001) and microwave irradiation method as described by Islam and Weil (1998), respectively.

The residual effects of manure and compost on soil greenhouse gas emissions and soil $\mathrm{C}$ and $\mathrm{N}$ indicators were evaluated from 14 June to 24 Nov. 1999 (four years after the last application of manure and compost). At each time of gas sampling, soil temperature at the $7.5-\mathrm{cm}$ depth was measured adjacent to the gas chamber. Air temperature data and winter soil temperatures were gathered from a weather station located $3 \mathrm{~km}$ from the experiment. Four 1.8-cm-diameter soil cores were collected at depth intervals of 0 to $7.5,7.5$ to 15 , and 15 to $30 \mathrm{~cm}$ within a 1-m distance from the gas-sampling chamber. 


\section{Gas Measurements}

Measurements of greenhouse gases were made with the vented surface gas chamber technique (Hutchinson and Mosier, 1981). Gas samplings were conducted on 14 June, 27 July, 31 Aug., 1 Oct., and 24 Nov. 1999. At each sampling date, a flux measurement was taken in each of the 18 plots (three replications in each of the six treatments). The chambers were removed between sampling dates. The chamber (a cylindrical surface chamber, $15 \mathrm{~cm}$ in diameter and $15 \mathrm{~cm}$ high) was placed on a weed-free representative interrow area within each plot. Interrow was chosen because it occupied $74 \%$ of the area (row area was defined as a 20 -cm-wide strip centered over the row). The chamber was inserted $7.5 \mathrm{~cm}$ deep into the soil and capped creating an effective headspace of $1334 \mathrm{~cm}^{3}$. Gas samples were collected from the chambers at 0,15 , and 30 min with a $20-\mathrm{mL}$ polypropylene syringe. Gas was sampled after purging the gas repeatedly 10 to 20 times with the syringe. The $20-\mathrm{mL}$ samples were transferred to $12-\mathrm{mL}$ evacuated serum vials and transported to the laboratory.

Gas samples collected were analyzed for $\mathrm{CO}_{2}, \mathrm{~N}_{2} \mathrm{O}$, and $\mathrm{CH}_{4}$ within $72 \mathrm{~h}$ after sampling. The $\mathrm{CO}_{2}$ content was determined with a gas-chromatographic system with a thermal conductivity detector maintained at $110^{\circ} \mathrm{C}$ as described by Weier et al. (1993). The $\mathrm{N}_{2} \mathrm{O}$ and $\mathrm{CH}_{4}$ contents were determined with an automated gas chromatographic system with a Poropak $\mathrm{Q}$ (Palo Alto, CA) column and electron capture detector, and a Poropak $\mathrm{N}$ column and flame ionization detector, respectively, as described by Arnold et al. (2001).

\section{Gas Flux Calculation}

For simplicity, gas concentrations measured at 0,15 , and $30 \mathrm{~min}$ are represented as $C_{0}, C_{15}$, and $C_{30}$, respectively. Our data indicated that gas concentration could steadily increase, steadily decrease, or fluctuate with time. Existence of flux (positive or negative) is determined by the difference of gas concentration (increase or decrease) with time. The absolute value of the difference between two gas concentrations $\left(C_{15}-\right.$ $C_{0}, C_{30}-C_{15}, C_{30}-C_{0}$ ) was considered greater than zero only if it was greater than two times the standard error of gas measurements in our laboratory as described by Arnold et al. (2001). Otherwise the concentration difference and thus gas flux was equal to zero. This approach was taken to ensure that the gas concentration difference exceeded laboratory measurement error.

If the gas concentration inside the chamber steadily increased with time $\left(C_{0}<C_{15}<C_{30}\right)$ in a nonlinear trend, that is, when the ratio of $\left(C_{15}-C_{0}\right) /\left(C_{30}-C_{15}\right)>1$, the flux calculation was made as described by Hutchinson and Mosier (1981):

$F=k d\left(\frac{273}{T}\right)\left(\frac{V}{A}\right) \frac{\left(C_{15}-C_{0}\right)^{2}}{\left(2 C_{15}-C_{30}-C_{0}\right) t} \ln \frac{\left(C_{15}-C_{0}\right)}{\left(C_{30}-C_{15}\right)}$

where $F$ is the rate of gas emission (mass ha $\mathrm{h}^{-1} \mathrm{~d}^{-1}$ ), $k$ is unit conversion, $d$ is gas density $\left(\mathrm{g} \mathrm{cm}^{-3}\right)$ at $273 \mathrm{~K}$ and $0.101 \mathrm{MPa}$ pressure, $T$ is the air temperature $(\mathrm{K})$ within the chamber, $V$ is the volume of air within the chamber $\left(\mathrm{cm}^{3}\right), A$ is the area of soil within the chamber $\left(\mathrm{cm}^{2}\right), C$ is gas concentration (percent $[\mathrm{v} / \mathrm{v}]$ for $\mathrm{CO}_{2}-\mathrm{C}$ and $\mathrm{ppm}[\mathrm{v} / \mathrm{v}]$ for $\mathrm{N}_{2} \mathrm{O}-\mathrm{N}$ and $\mathrm{CH}_{4}-\mathrm{C}$ ), and $t$ is $15 \mathrm{~min}$ (duration from $C_{0}$ to $C_{15}$ ). The value of $k$ is $1.44 \times 10^{6}$ for $\mathrm{CO}_{2}-\mathrm{C}$ and 144 for $\mathrm{N}_{2} \mathrm{O}-\mathrm{N}$ and $\mathrm{CH}_{4}-\mathrm{C}$. The value of $d$ is $5.36 \times 10^{-4} \mathrm{~g} \mathrm{~cm}^{-3}$ for $\mathrm{CO}_{2}-\mathrm{C}$ and $\mathrm{CH}_{4}-\mathrm{C}$ and $1.25 \times 10^{-3} \mathrm{~g} \mathrm{~cm}^{-3}$ for $\mathrm{N}_{2} \mathrm{O}-\mathrm{N}$. Gas density was calculated based on the assumption that $1 \mathrm{~mol}$ of air occupies a 22.4-L volume at $273 \mathrm{~K}$ and $0.101 \mathrm{MPa}$. When concentration decreased with time $\left(C_{0}>C_{15}>C_{30}\right)$ in a nonlinear trend, that is, when the ratio of $\left(C_{15}-C_{0}\right) /\left(C_{30}-C_{15}\right)>1$, the flux calculation was similar to Eq. [1] above, except that the value of $F$ is negative (gas uptake by soil system).

If the gas concentration inside the chamber steadily increased $\left(C_{0}<C_{15}<C_{30}\right)$ or decreased with time $\left(C_{0}>C_{15}>\right.$ $\left.C_{30}\right)$ and the ratio of $\left(C_{15}-C_{0}\right) /\left(C_{30}-C_{15}\right) \leq 1$, then the flux was calculated from the equation:

$$
F=k d\left(\frac{273}{T}\right)\left(\frac{V}{A}\right)\left(\frac{\Delta C}{\Delta t}\right)
$$

where $\Delta C / \Delta t$ is the average rate of change of concentration between $C_{15}-C_{0}$ and $C_{30}-C_{15}$.

This approach avoids underestimation of flux, especially when the rate of change of concentration between 0 and 15 min is much lower than that between 15 and $30 \mathrm{~min}$. When gas concentration fluctuates with time $\left(C_{0}<C_{15}>C_{30}\right.$ or $C_{0}>$ $C_{15}<C_{30}$ ), it indicates that gas flux trend is inconsistent within a 30-min period (emission followed by uptake or vice versa). In this case, $\Delta C / \Delta t$ is represented by the average rate of change of concentrations of $C_{15}-C_{0}$ and $C_{30}-C_{0}$.

\section{Estimation of Daily and Annual Fluxes}

Since gas measurements were not made every day, daily gas fluxes were estimated with the relationships between measured fluxes and soil properties. Total $\mathrm{CO}_{2}-\mathrm{C}$ flux is the sum of flux contributions of soil microorganisms and invertebrates (especially during nongrowing season), and root plus root-induced microbial respiration (during growing season). For lack of better terms and for simplicity, $\mathrm{CO}_{2}$ flux from root and root-induced microbial respiration were grouped as root respiration. Among measured soil properties, soil temperature best described $\mathrm{CO}_{2}-\mathrm{C}$ flux from microorganisms and invertebrates as a simple linear function $\left(0.05\right.$ probability level and $\left.r^{2}=0.30\right)$. Soil temperature data (from our soil measurements) was used to estimate daily gas-flux contribution of soil microorganisms and invertebrates. Root respiration during corn growth was determined as the difference between measured gas flux and the estimated gas flux of soil microorganisms and invertebrates. Daily root respiration during the growing season was estimated by linear interpolation of root respiration between consecutive gas measurements. Annual (1 Jan.-31 Dec. 1999) $\mathrm{CO}_{2}$ emission was estimated by totaling the estimated (based on soil temperature) and measured daily gas fluxes. Assumption of temporal linearity between sampling periods may not be always valid, therefore the annual $\mathrm{CO}_{2}$ emissions are estimates that may not be the accurate annual losses of $\mathrm{CO}_{2}$.

Interpolations for daily fluxes of $\mathrm{N}_{2} \mathrm{O}$ or $\mathrm{CH}_{4}$ were not done because there was no clear relationship between $\mathrm{N}_{2} \mathrm{O}$ or $\mathrm{CH}_{4}$ flux with other measured soil variables such as soil temperature or WFP.

To evaluate the effects of WFP, EC, and $\mathrm{pH}$ on $\mathrm{CO}_{2}-\mathrm{C}$ fluxes across different sampling times and soil temperatures, fluxes were adjusted to a uniform soil temperature of $25^{\circ} \mathrm{C}$ by using the following equation as described by Parkin et al. (1996):

$$
F_{25}=F_{\mathrm{ST}} \times Q_{10}^{[(25-\mathrm{ST}) / 10]}
$$

where $F_{25}$ is projected flux at $25^{\circ} \mathrm{C}, F_{\mathrm{ST}}$ is measured flux at soil temperature (ST) $\left(7.5-\mathrm{cm}\right.$ depth), and $Q_{10}$ is the increase of flux for every $10^{\circ} \mathrm{C}$ increase in soil temperature. The $Q_{10}$ was derived from a linear relationship between gas fluxes and temperature.

\section{Statistical Analysis}

Analysis of variance was conducted with the Mixed Model of SAS (SAS Institute, 1992; Littell et al., 1996). In this analy- 
sis, treatment was the component of fixed effect and replication was the random effect. To evaluate how treatment means and differences change with time, analyses of repeated measures were performed by using autoregressive order 1 covariance (Littell et al., 1996). A probability level $<0.05$ was considered significant.

\section{RESULTS AND DISCUSSION}

\section{Differences of Total Carbon Input into Soil}

Carbon inputs into the soil from manure, composted manure, plants, and rhizodeposits are presented in $\mathrm{Ta}-$ ble 1 . The plant $\mathrm{C}$ included measured stover $\mathrm{C}$, the estimated $\mathrm{C}$ from roots, rhizodeposits (root turnover, sloughing, and exudates), and weeds. The 7-yr cumulative stover C input in the CTL plot was 10 to $20 \%$ lower than the FRT, MN1, MN2, CP1, and CP2 treatments. Organic applications from 1992 to 1995 (Table 1) increased total $\mathrm{C}$ input into soil in plots treated with manure and compost by $30 \%$ over the FRT plot $(10 \mathrm{Mg}$ $\mathrm{ha}^{-1}$ ) and $50 \%$ over the CTL plot $\left(15 \mathrm{Mg} \mathrm{ha}^{-1}\right)$.

\section{Soil Carbon Gas Fluxes}

\section{Carbon Dioxide}

Soil receiving manure or compost had similar $\mathrm{CO}_{2}$ emission as the control or fertilized soil (Fig. 1). The residual effect of manure or compost on $\mathrm{CO}_{2}$ emission was not significant four years after manure and compost applications had stopped. It appears that the large native pool of organic matter and the annual addition of $\mathrm{C}$ from plant materials (more than 4.1 $\mathrm{Mg} \mathrm{C} \mathrm{ha}^{-1} \mathrm{yr}^{-1}$ ) after termination of manure application masked the resid- ual effects (if any) of manure and compost amendments on $\mathrm{CO}_{2}-\mathrm{C}$ emission.

The $\mathrm{CO}_{2}-\mathrm{C}$ fluxes changed with time of sampling (Fig. 1). The measured $\mathrm{CO}_{2}-\mathrm{C}$ fluxes (average across treatments) were in this order: 27 July $>14$ June $=$ 31 August $>1$ October $=24$ November. The corresponding flux for each date was 47.5, 30.9, 24.6, 10.7, and $6.1 \mathrm{~kg} \mathrm{CO}_{2}-\mathrm{C} \mathrm{ha}^{-1} \mathrm{~d}^{-1}$, respectively. Higher $\mathrm{CO}_{2}-\mathrm{C}$ fluxes during the growing season than those after harvest were due to plant root respiration (or root-induced microbial respiration) and higher soil temperature during the growing season. Soil temperature differed among sampling times in this order: 14 June $=27$ July = 31 August $>1$ October $>24$ November. The growing season soil temperatures on 14 June, 27 July, and 31 August ranged from 21 to $32^{\circ} \mathrm{C}$ while the nongrowing season soil temperature on 31 October and 24 November ranged from 2 to $17^{\circ} \mathrm{C}$ (Fig. 2).

Analysis of combined data indicated that $\mathrm{CO}_{2}-\mathrm{C}$ flux during the nongrowing season was best described by simple linear function of soil temperature (Fig. 2) with minimal interference (if any) from root activities. For every $10^{\circ} \mathrm{C}\left(Q_{10}\right)$ increase in temperature between 5 and $15^{\circ} \mathrm{C}$, the $\mathrm{CO}_{2}-\mathrm{C}$ flux increased 1.8 -fold. This apparent $Q_{10}$ value of 1.8 is lower than the reported $Q_{10}$ values (between 5 and $15^{\circ} \mathrm{C}$ ) of 2.3 (Kessavalou et al., 1998) and 3 (Lessard et al., 1994). Exclusion of growing season $\mathrm{CO}_{2}-\mathrm{C}$ flux from linear regression analysis (Fig. 2) caused our $Q_{10}$ value to be lower than 2.0. Inclusion of growing-season $\mathrm{CO}_{2}$ flux in the regression analysis would inflate the $Q_{10}$ value because of the compounding temperature effects on root respiration. Inflated values of $Q_{10}$ would indicate negative root respiration during the growing season, which in our case would be unrealistic.

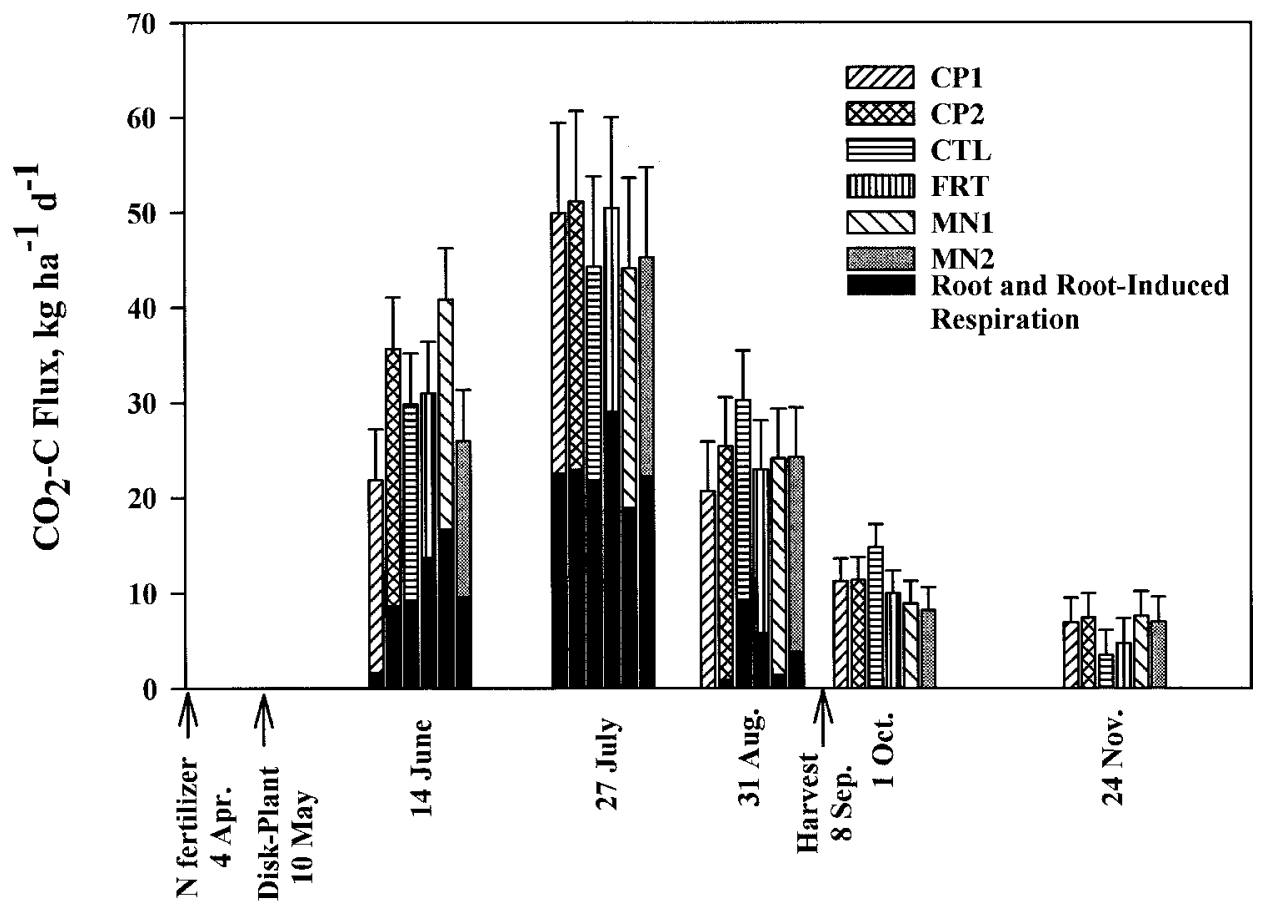

Sampling Date

Fig. 1. The residual effects of manure, compost, and $\mathrm{N}$ fertilizer application on soil emission of $\mathrm{CO}_{2}$ from root respiration and microbial activities at various sampling times in 1999. Vertical bars are standard errors $(n=3)$ of the least-square means of treatments. 
In a laboratory experiment, Linn and Doran (1984) found that microbial respiration increased with WFP (from 10 to $60 \%$ ) reaching a maximum at WFP of $60 \%$ and then microbial respiration decreased for WFP > $60 \%$. In our study the effects of WFP on $\mathrm{CO}_{2}-\mathrm{C}$ flux were inconsistent. A possible reason, besides variability of soil environment in the field, is that the moisture range did not vary widely among sampling times. The WFP ranged from 34 to $50 \%$ at all sampling times in the 0 - to $7.5-\mathrm{cm}$ depth except on 24 November, where WFP ranged from 50 to $80 \%$. Within each sampling time, the WFP was similar among treatments in all soil depths. These similarities indicate that when the organic matter pool was large and plots were under similar cultural practices, the residual effects of applied manure and compost on WFP were not detectable.

Using the $Q_{10}$ value of 1.8 , the projected root respiration at $25^{\circ} \mathrm{C}$ during the growing season showed no difference among treatments within each sampling time (Fig. 1). However, there were significant differences in root respiration among sampling times in the order: 27 July $>14$ June $>31$ August (Fig. 1). The average root respiration rates on 27 July, 14 June, and 31 August were $23.0,10.0$, and $3.1 \mathrm{~kg} \mathrm{CO}_{2}-\mathrm{Cha}^{-1} \mathrm{~d}^{-1}$, respectively. These root-respiration rates were equivalent to 51,32 , and $10 \%$ of total $\mathrm{CO}_{2}-\mathrm{C}$ fluxes for those dates, respectively. As with Eghball and Maranville (1993), corn root volume on 14 June (when plants have six to eight leaves) was expected to be smaller than that of 27 July (when corn was silking and pollinating), causing less root respiration. The root activity on 31 August was lower than that on 27 July or 14 June because corn reached the beginning of dent stage and approached physiological maturity on 31 August. Soil temperature and WFP were not expected to be the cause of these differences because they were similar among the sampling dates. The average soil temperatures on 14 June, 27 July, and 31 August were 26,27 , and $27^{\circ} \mathrm{C}$, and WFP values were 51,52 , and $54 \%$, respectively.

Based on linear interpolation of root-related respiration and the relationship between microbial respiration

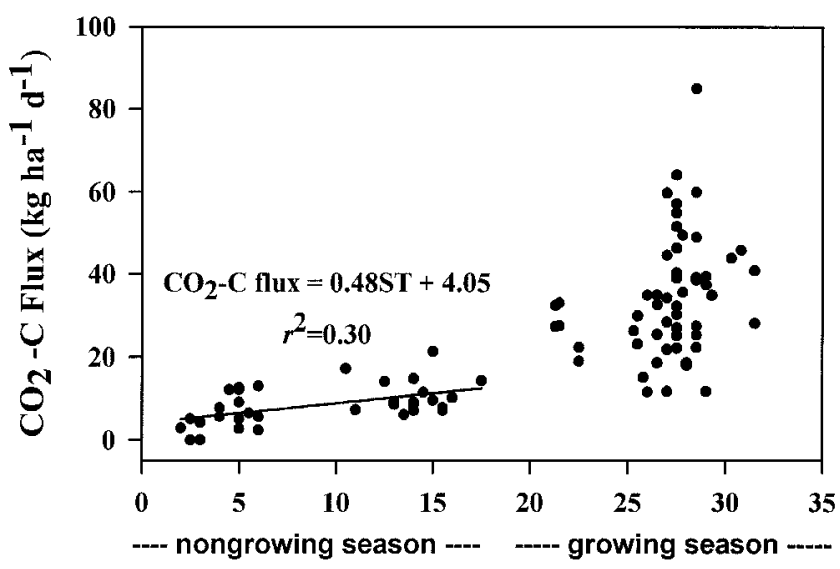

Temperature $\left({ }^{\circ} \mathrm{C}\right)$

Fig. 2. Effects of soil temperature on $\mathrm{CO}_{2}$ fluxes during the growing season and nongrowing season in 1999. with soil temperature, the estimated annual losses of $\mathrm{CO}_{2}-\mathrm{C}$ in 1999 were $4.4,5.1,4.4,4.5,4.2$, and $4.2 \mathrm{Mg}$ ha $^{-1}$ from the CTL, FRT, MN1, MN2, CP1, and CP2 plots, respectively. The estimated annual loss of $\mathrm{CO}_{2}-\mathrm{C}$ from the CTL and FRT plots was close (within $0.2 \mathrm{Mg}$ $\mathrm{C} \mathrm{ha}{ }^{-1}$ ) to the corresponding average annual plant $\mathrm{C}$ input from plant materials of 4.2 and $4.9 \mathrm{Mg} \mathrm{ha}^{-1}$ in CTL and FRT plots, respectively. This finding suggests that for a spring disking tillage system, returning corn plant materials to the soil is necessary to maintain a balance between $\mathrm{C}$ input into the soil and $\mathrm{CO}_{2}-\mathrm{C}$ emissions from the soil.

\section{Methane}

Fluxes of $\mathrm{CH}_{4}-\mathrm{C}$ were not different among treatments at each sampling time and there was no consistent pattern of fluxes (Fig. 3). The soil could be a sink (negative fluxes) at a sampling time and could be a source (positive fluxes) at another time, despite the similarity of environmental factors among sampling times. High standard errors of means in each sampling time indicated that $\mathrm{CH}_{4}-\mathrm{C}$ fluxes were not significantly different from zero in most cases at the 0.05 probability level. The marginal $\mathrm{CH}_{4}-\mathrm{C}$ flux in our study was similar to the observations of Conrad (1996). Conrad (1996) pointed out that in most upland soils, $\mathrm{CH}_{4}-\mathrm{C}$ production is usually absent or marginal because the $\mathrm{CH}_{4}-\mathrm{C}$ flux is dominated by $\mathrm{CH}_{4}-\mathrm{C}$ oxidation, which is dependent on the dynamic composition of methanotrophs and other $\mathrm{CH}_{4}$-oxidizing microbes such as nitrifiers. The treatment means of $\mathrm{CH}_{4}-\mathrm{C}$ fluxes pooled from all samplings ( $\pm \mathrm{SE}$ of $1.64 \mathrm{~g}$ $\mathrm{ha}^{-1} \mathrm{~d}^{-1}$ ) were $0.0,0.7,1.8,-0.18$, and $0.79 \mathrm{~g} \mathrm{ha}^{-1} \mathrm{~d}^{-1}$ on 14 June, 27 July, 31 August, 1 October, and 24 November, respectively. The pooled data from all samplings showed no definite relationship between $\mathrm{CH}_{4}-\mathrm{C}$ fluxes with soil temperature, WFP, EC, or $\mathrm{pH}$.

The effect of $\mathrm{CH}_{4}-\mathrm{C}$ emission on depletion of soil $\mathrm{C}$ was much smaller than that of $\mathrm{CO}_{2}-\mathrm{C}$. Even by using the highest means of $1.8 \mathrm{~g} \mathrm{C} \mathrm{ha}^{-1} \mathrm{~d}^{-1}$, estimated annual emission of $\mathrm{CH}_{4}-\mathrm{C}$ was less than $1 \mathrm{~kg} \mathrm{ha}^{-1} \mathrm{yr}^{-1}$, practically null compared with the $4.4 \mathrm{Mg} \mathrm{ha}^{-1} \mathrm{yr}^{-1}$ of $\mathrm{CO}_{2}-\mathrm{C}$ from CTL plots. Based on a 20 -yr global warming potential (GWP) of 1 for $\mathrm{CO}_{2}$ and 56 for $\mathrm{CH}_{4}$ (Intergovernmental Panel on Climate Change, 1996), the GWP of $1 \mathrm{~kg} \mathrm{CH}_{4}-\mathrm{C} \mathrm{ha}^{-1} \mathrm{yr}^{-1}$ was much smaller than GWP of 4.4 $\mathrm{Mg} \mathrm{ha}^{-1} \mathrm{yr}^{-1}$ of soil $\mathrm{CO}_{2}-\mathrm{C}$ emission. In the same manner, by using $-0.2 \mathrm{~g} \mathrm{ha}^{-1} \mathrm{~d}^{-1}$ of $\mathrm{CH}_{4}-\mathrm{C}$ uptake, the estimated annual uptake of $\mathrm{CH}_{4}-\mathrm{C}$ by the soil is less than $0.1 \mathrm{~kg} \mathrm{ha}^{-1} \mathrm{yr}^{-1}$, which was too small to consider in the soil C dynamic involving the annual incorporation of sequestered carbon by plant material into the soil (Table 1).

\section{Differences in Total Nitrogen Input into Soil}

Total $\mathrm{N}$ input into the soil, $\mathrm{N}$ removed from the soil by grain, and total $\mathrm{N}$ recycled as plant materials differ with treatments. In the CTL plot (no $\mathrm{N}$ input), $62 \mathrm{~kg}$ $\mathrm{N} \mathrm{ha}{ }^{-1} \mathrm{yr}^{-1}$ soil $\mathrm{N}$ was removed by grain. In the FRT plots, average annual $\mathrm{N}$ input into soil $\left(107 \mathrm{~kg} \mathrm{~N} \mathrm{ha}^{-1}\right.$ $\mathrm{yr}^{-1}$ ) was slightly higher than total $\mathrm{N}$ removed by grain 


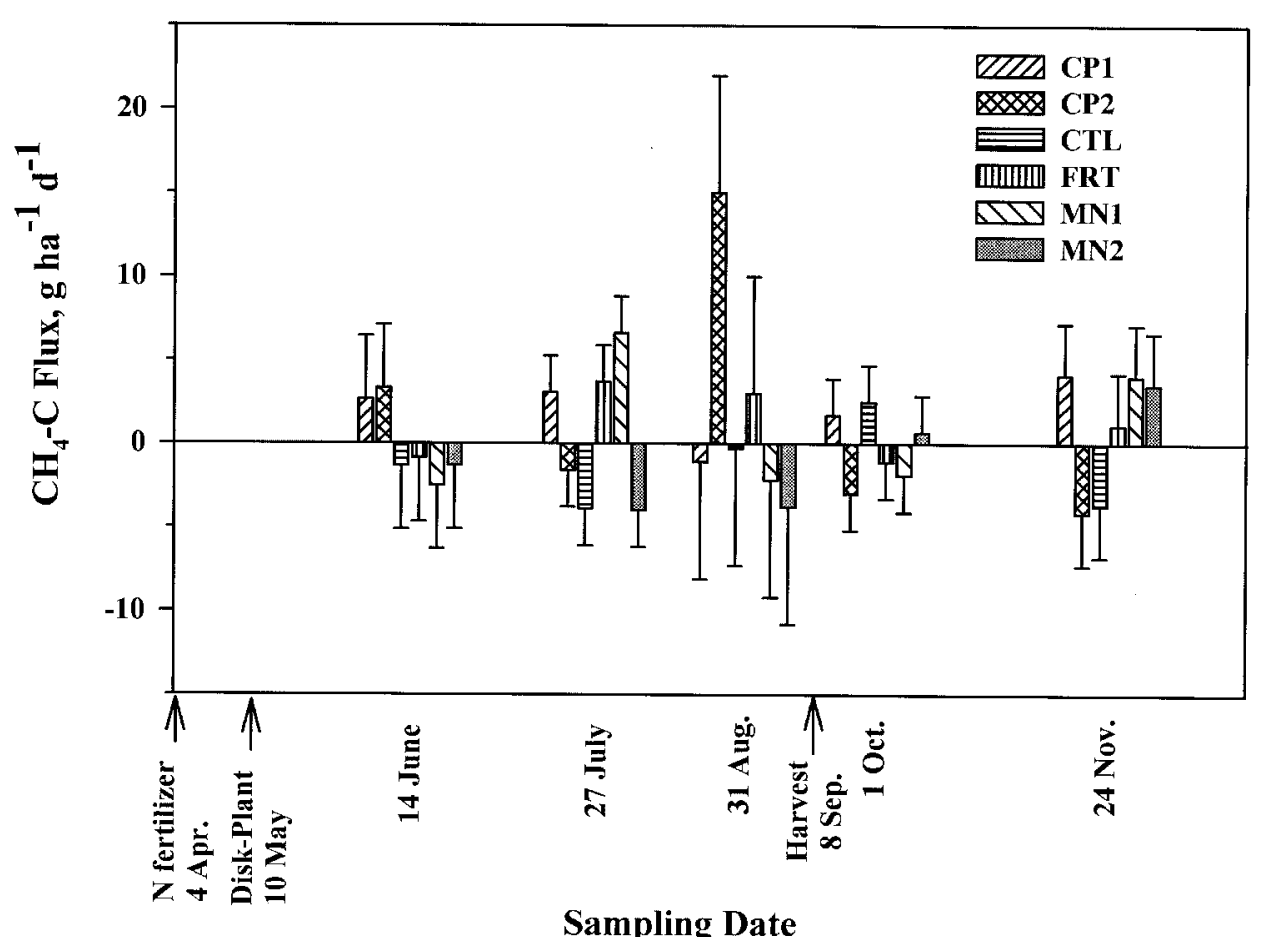

Fig. 3. The residual effects of manure, compost, and $\mathbf{N}$ fertilizer application on fluxes of methane from soil at various sampling times in 1999. Vertical bars are standard errors $(n=3)$ of the least-square means of treatments.

(101 kg N ha-1 $\mathrm{yr}^{-1}$ ). In the manure- and composttreated plots, total $\mathrm{N}$ input was much higher than the $\mathrm{N}$ uptake.

\section{Soil Nitrous Oxide Emission}

Fluxes of $\mathrm{N}_{2} \mathrm{O}-\mathrm{N}$ were not different among treatments at each sampling time except on 14 June where CP1 and $\mathrm{CP} 2$ resulted in greater $\mathrm{N}_{2} \mathrm{O}-\mathrm{N}$ fluxes than other treatments at the 0.10 probability level (Fig. 4). The means $\left( \pm \mathrm{SE}\right.$ of $\left.7.9 \mathrm{~g} \mathrm{ha}^{-1} \mathrm{~d}^{-1}\right)$ of $\mathrm{N}_{2} \mathrm{O}-\mathrm{N}$ fluxes on 14 June from the CP1 and CP2 plots $(30.5$, and $24.5 \mathrm{~g}$ $\mathrm{ha}^{-1} \mathrm{~d}^{-1}$, respectively) were higher than the other treatments (less than $11 \mathrm{~g} \mathrm{ha}^{-1} \mathrm{~d}^{-1}$ ). Kessavalou et al. (1998) associated high $\mathrm{N}_{2} \mathrm{O}-\mathrm{N}$ flux in June with WFP being

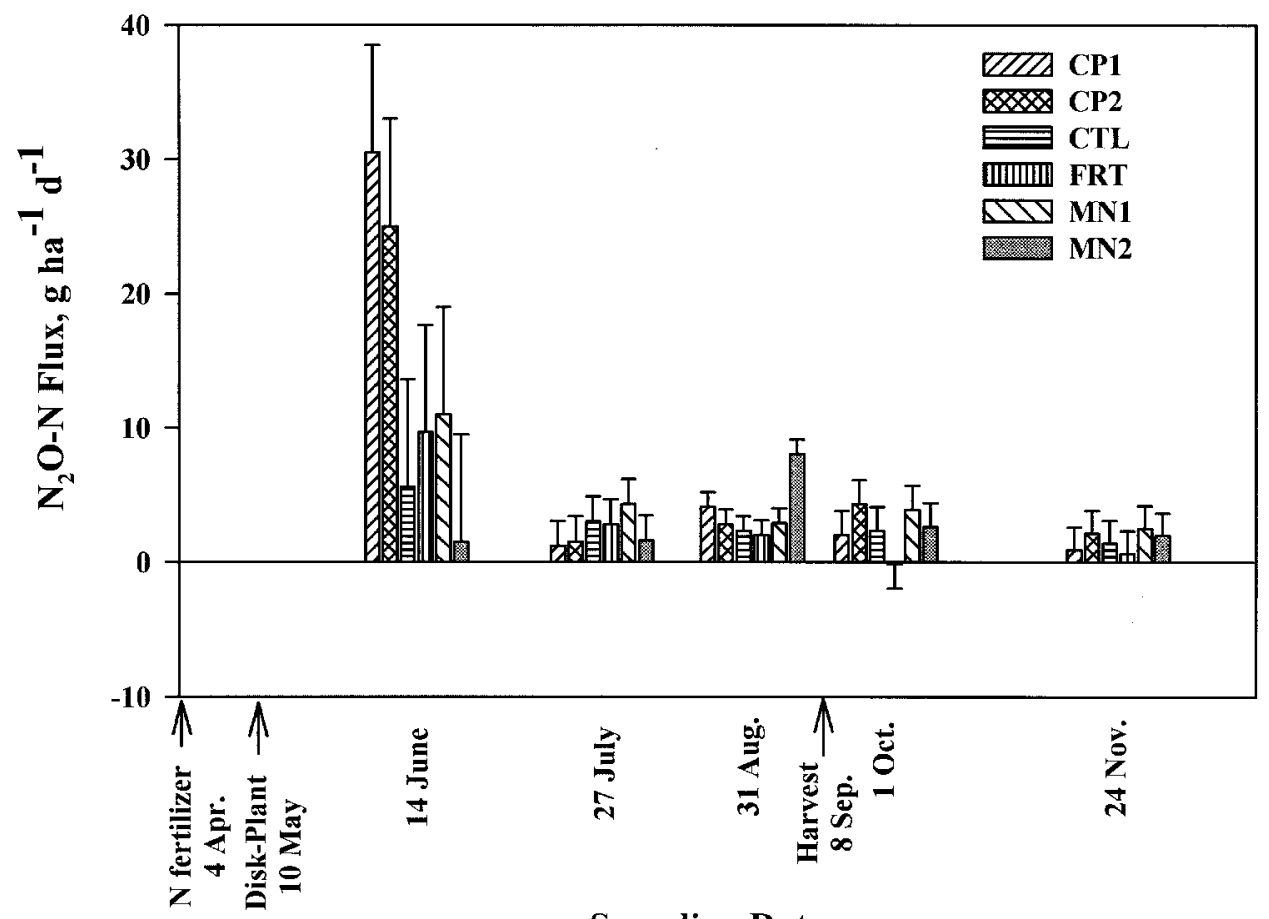

Sampling Date

Fig. 4. The residual effects of manure, compost, and $\mathbf{N}$ fertilizer application on soil emission of nitrous oxide at various sampling times in 1999. Vertical bars are standard errors $(n=3)$ of the least-square means of treatments. 
greater than $60 \%$. Since WFP was similar among the treatments (less than $55 \%$ in the 0 - to $15-\mathrm{cm}$ depth), the difference could be due to nitrification as shown by soil EC. A significant linear relationship between $\mathrm{EC}_{1: 1}$ level and soil nitrate concentration $(\mathrm{EC}=0.008 \times$ $\left.\mathrm{NO}_{3}-\mathrm{N}, r^{2}=0.47, P<0.001\right)$ indicated that $47 \%$ of the EC variability was explained by soil nitrate. Weier et al. (1993) observed an increase in $\mathrm{N}_{2} \mathrm{O}$ emission with increasing $\mathrm{EC}_{1: 1}$. Residual soil $\mathrm{EC}_{1: 1}$ values in $\mathrm{CP} 1$ and $\mathrm{CP} 2$ on 14 June (ranging from 0.41 to $0.5 \mathrm{dS} \mathrm{m}^{-1}$ ) were higher than those of other treatments (ranging from 0.25 to $0.40 \mathrm{dS} \mathrm{m}^{-1}$ ). Rapid increase in spring temperature on recently tilled soil may have increased mineralization, ammonification, and nitrification processes resulting in higher nitrate and thus increased $\mathrm{N}_{2} \mathrm{O}$ flux in June. According to Bremner and Blackmer (1978) and Bremner et al. (1981), the increase in ammonification and nitrification processes can result in increased nitrous oxide emission, especially under aerobic conditions.

The $\mathrm{N}_{2} \mathrm{O}-\mathrm{N}$ fluxes were lower on 27 July compared with 14 June while root activities were higher on 27 July than on 14 June and 31 August (Fig. 1 and 4). This indicates that root activities had a significant influence on $\mathrm{CO}_{2}-\mathrm{C}$ flux but were not related to $\mathrm{N}_{2} \mathrm{O}-\mathrm{N}$ flux from soil. The means $\left( \pm \mathrm{SE}\right.$ of $\left.1.6 \mathrm{~g} \mathrm{ha}^{-1} \mathrm{~d}^{-1}\right)$ of $\mathrm{N}_{2} \mathrm{O}-\mathrm{N}$ flux on 14 June, 27 July, and 31 August were 13.8, 2.4, and $3.7 \mathrm{~g} \mathrm{ha}^{-1} \mathrm{~d}^{-1}$, respectively. The $\mathrm{N}_{2} \mathrm{O}-\mathrm{N}$ flux means on 1 October and 24 November were 2.5 and $1.5 \mathrm{~g} \mathrm{ha}^{-1} \mathrm{~d}^{-1}$, respectively, indicating no flux differences for the nongrowing season sampling times. Pooling all $\mathrm{N}_{2} \mathrm{O}-\mathrm{N}$ data, there was no significant linear relationship between $\mathrm{N}_{2} \mathrm{O}-\mathrm{N}$ flux with soil temperature at WFP $<60 \%$ or WFP $>60 \%$. Lessard et al. (1996) showed that $\mathrm{N}_{2} \mathrm{O}$ flux at the soil surface is mainly driven by diffusion process rather than soil temperature. There was also no significant relationship between $\mathrm{N}_{2} \mathrm{O}-\mathrm{N}$ emission with soil $\mathrm{pH}_{1: 1}$ or $\mathrm{EC}_{1: 1}$ (except on the 14 June sampling).

Nitrogen loss by way of $\mathrm{N}_{2} \mathrm{O}-\mathrm{N}$ emission four years after manure or compost application was negligible. No $\mathrm{N}_{2} \mathrm{O}$ measurement was taken one, two, or three years after manure or compost application. According to a study by Wagner-Riddle et al. (1997), $\mathrm{N}_{2} \mathrm{O}$ emission during June to November was nearly zero within one or two years after two-year manure application. By using the average flux of 14 June, 27 July, and 31 August to represent the daily $\mathrm{N}_{2} \mathrm{O}-\mathrm{N}$ flux during the growing sea- son (from corn emergence on 1 May to corn maturity on 30 September) and the average flux of 1 October and 24 November to represent daily $\mathrm{N}_{2} \mathrm{O}-\mathrm{N}$ flux during the nongrowing season, estimated annual emission of $\mathrm{N}_{2} \mathrm{O}-\mathrm{N}$ was $1.4 \mathrm{~kg} \mathrm{ha}^{-1}$, which was slightly less than $1 \%$ of the $151 \mathrm{~kg} \mathrm{~N} \mathrm{ha}^{-1}$ applied to the FRT plot in spring 1999. This estimate is similar to the $\mathrm{N}$ loss as $\mathrm{N}_{2} \mathrm{O}-\mathrm{N}$ (ranging from 1 to $1.5 \%$ of applied $\mathrm{N}$ ) under corn irrigated with high-nitrate ground water during a dry year (Qian et al., 1997). The estimate of $1 \% \mathrm{~N}_{2} \mathrm{O}-\mathrm{N}$ loss per $\mathrm{N}$ added was also within the range $(0.40-1.57 \%)$ of $\mathrm{N}_{2} \mathrm{O}-\mathrm{N}$ losses in various studies summarized by Lessard et al. (1996).

The residual effects of manure or compost pose no additional threat to the atmospheric quality. Also it poses no threat to the depletion of soil N. The $1.4 \mathrm{~kg}$ ha $^{-1} \mathrm{yr}^{-1}$ loss of soil $\mathrm{N}$ as $\mathrm{N}_{2} \mathrm{O}-\mathrm{N}$ was negligible considering the large pool (more than $3.1 \mathrm{Mg} \mathrm{ha}^{-1}$ ) of total soil $\mathrm{N}$. The large quantity of soil total $\mathrm{N}$ and the annual internal recycling of more than $34 \mathrm{~kg}$ plant $\mathrm{N} \mathrm{ha}^{-1} \mathrm{yr}^{-1}$ (Table 2) after termination of manure application may have masked the residual effects (if any) of manure and compost amendments on $\mathrm{N}_{2} \mathrm{O}-\mathrm{N}$ fluxes.

\section{Assessment of Soil Properties Relevant to Gas Emission}

\section{Soil pH}

Soil $\mathrm{pH}$ at the 0 - to $7.5-\mathrm{cm}$ depth varied among treatments (Table 3 ). The $\mathrm{pH}$ in FRT plots (consistently <5.6) was lower than that of CTL plots (consistently >6.1). The $\mathrm{pH}$ in the FRT plots was lower than the accepted $\mathrm{pH}$ (between 6 to 7.5) for general plant growth and microbial activity (Smith and Doran, 1996). Acidity in FRT plots was produced during the formation of nitrate from ammonium fertilizer applied to the soil (Brady, 1984). In Canada, Bouman et al. (1995) showed a marked decrease of $\mathrm{pH}$ in prairie soil due to a longterm application of urea and anhydrous ammonia. The $\mathrm{pH}$ of CTL plots was consistently lower than that of $\mathrm{CP} 1$ or $\mathrm{CP} 2$ (consistently $>6.5$ ). Soil $\mathrm{pH}$ values at the 0 - to $7.5-\mathrm{cm}$ depth were in the order: $\mathrm{CP} 1=\mathrm{CP} 2>$ MN1 $=$ MN2 $>$ CTL $>$ FRT (Table 3). Residual effects of annual application of ammonium nitrate and diammonium phosphate resulted in a decrease of $0.5 \mathrm{pH}$ unit

Table 3. The residual effects of compost, manure, and $\mathrm{N}$ fertilizer on soil $\mathrm{pH}_{1: 1}$, electrical conductivity $\left(\mathrm{EC}_{1: 1}\right.$, where the subscript 1:1 indicates soil weight to water ratio), and concentrations of soil nitrate at the 0 - to $7.5-$, $7.5-$ to $15-$, and $15-$ to $30-\mathrm{cm}$ depths on 22 Oct. 1999.

\begin{tabular}{|c|c|c|c|c|c|c|c|c|c|}
\hline \multirow[b]{2}{*}{ Treatment $\dagger$} & \multicolumn{3}{|c|}{ Soil pH } & \multicolumn{3}{|c|}{ Soil EC } & \multicolumn{3}{|c|}{ Soil $\mathrm{NO}_{3}$ concentration } \\
\hline & $0-7.5 \mathrm{~cm}$ & $7.5-15 \mathrm{~cm}$ & $15-30 \mathrm{~cm}$ & $0-7.5 \mathrm{~cm}$ & $7.5-15 \mathrm{~cm}$ & $15-30 \mathrm{~cm}$ & $0-7.5 \mathrm{~cm}$ & $7.5-15 \mathrm{~cm}$ & $15-30 \mathrm{~cm}$ \\
\hline & & & & & $\mathbf{d S} \mathbf{m}^{-1}$ & & & $\mathbf{m g ~ N} \mathbf{k g}^{-1}$ & \\
\hline CTL & $6.2 \mathrm{c}$ & $6.2 \mathrm{c}$ & $6.2 \mathrm{c}$ & $0.34 d$ & $0.26 d$ & $0.26 c$ & $15.2 \mathrm{a}$ & 10.1a & $6.7 \mathrm{~b}$ \\
\hline FRT & $5.5 \mathrm{~d}$ & $5.9 \mathrm{~d}$ & $6.1 \mathrm{c}$ & $0.39 \mathrm{c}$ & $0.31 \mathrm{c}$ & $0.29 a$ & 25.5a & 13.0a & 13.3a \\
\hline CP1 & $6.6 a$ & $6.6 \mathrm{a}$ & $6.5 a$ & $0.49 a$ & $0.36 \mathrm{~b}$ & $0.30 \mathrm{a}$ & $20.0 \mathrm{a}$ & 11.9a & $8.5 \mathrm{~b}$ \\
\hline CP2 & $6.6 \mathrm{a}$ & $6.6 a$ & 6.4ab & $0.49 a$ & $0.39 \mathrm{a}$ & $0.28 a$ & $20.6 a$ & 12.9a & $8.9 \mathrm{~b}$ \\
\hline MN1 & $6.5 \mathrm{~b}$ & $6.4 \mathrm{~b}$ & $6.4 \mathrm{~b}$ & $0.41 b c$ & $0.31 \mathrm{c}$ & $0.26 c$ & $22.7 \mathrm{a}$ & $12.7 \mathrm{a}$ & $8.6 b$ \\
\hline MN2 & $6.4 \mathrm{~b}$ & $6.4 \mathrm{~b}$ & 6.3b & $\mathbf{0 . 4 2 b}$ & $0.30 \mathrm{c}$ & $0.25 \mathrm{c}$ & $20.7 a$ & $9.0 \mathrm{a}$ & $6.6 \mathrm{~b}$ \\
\hline
\end{tabular}

† CTL, control; FRT, synthetic N fertilizer; CP1, compost applied annually; CP2, compost applied biennially; MN1, manure applied annually; MN2, manure applied biennially.

$\$$ Values in the same column followed by different letter are significantly different at $P=0.05$. 
compared with CTL plots and 0.7 to 1.0 units compared with manure or compost treatment. Lime contained in the manure and compost increased the soil $\mathrm{pH}$ (Eghball, 1999).

Soil $\mathrm{pH}$ values at the 7.5- to $15-\mathrm{cm}$ depth were in the order: $\mathrm{CP} 1=\mathrm{CP} 2>\mathrm{MN} 1=\mathrm{MN} 2>\mathrm{CTL}>\mathrm{FRT}$, which is similar to that of $\mathrm{pH}$ at the $0-$ to $7.5-\mathrm{cm}$ depth. The $\mathrm{pH}$ of the FRT plots (ranging from 5.8 to 6.0) was lower than that of the CTL plots (consistently >6.2) and the $\mathrm{pH}$ of the CTL plots was lower than those of $\mathrm{CP} 1$ or $\mathrm{CP} 2$ (consistently $>6.5$ ).

Soil $\mathrm{pH}$ at the 15 - to $30-\mathrm{cm}$ depth varied among treatments at each sampling date except on 31 August $(P=$ 0.08 ). Different from the $\mathrm{pH}$ at the 0 - to 7.5- and 7.5to $15-\mathrm{cm}$ depths, the treatment $\mathrm{pH}$ averages were 6.0 or greater, indicating less acidification at deeper depths. The average $\mathrm{pH}$ in the FRT plots (ranging from 6 to 6.2) was similar to that in CTL plots.

\section{Soil Electrical Conductivity}

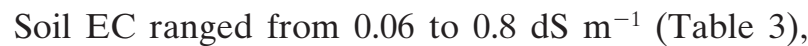
which was within the range acceptable for general plant growth and microbial activity (Smith and Doran, 1996). Soil EC at the 0- to $7.5-\mathrm{cm}$ depth varied among treatments. The EC in CP1 and CP2 plots was always higher than EC of the CTL plots. Soil EC at the 0- to $7.5-\mathrm{cm}$ depth decreased among treatments in the order: $\mathrm{CP} 2=$ $\mathrm{CP} 1>\mathrm{MN} 2=\mathrm{MN} 1=\mathrm{FRT}>\mathrm{CTL}$. Similar to the 0 - to $7.5-\mathrm{cm}$ depth, soil EC at the 7.5- to $15-\mathrm{cm}$ depth was higher in the compost treatments than in other treatments.

Soil EC at the 15- to 30-cm depth was in the order: $\mathrm{CP} 2=\mathrm{CP} 1=\mathrm{FRT}>\mathrm{CTL}=\mathrm{MN} 1=\mathrm{MN} 2$. Despite small differences $\left(<0.05 \mathrm{dS} \mathrm{m}^{-1}\right)$ among treatments, salts from compost and nitrate from FRT plots reached deeper soil than the manure treatment. Higher EC levels in deeper soils of the FRT plots as compared with the CTL plots was partially due to nitrate leaching, as a significant linear relationship was observed between EC and soil nitrate concentration.

\section{Soil Nitrate}

There was no significant effect of treatments on soil nitrate concentration at the $0-$ to $7.5-$ or $7.5-$ to $15-\mathrm{cm}$ depths (Table 3). Soil nitrate concentration decreased significantly with depth in all treatments except the FRT plots, which received $\mathrm{NH}_{4} \mathrm{NO}_{3}$ in 1999. Due to leaching of spring-applied ammonium nitrate, nitrate $\mathrm{N}$ concentration at the 15- to $30-\mathrm{cm}$ depth (Table 3 ) and its total amount at the 0 - to $30-\mathrm{cm}$ depth (Table 4) was higher in the FRT than the other treatments. The decrease of nitrate with depth and the similarity between the CTL plots and the manure- and compost-treated plots indicates that the postharvest residual effects of manure and compost on nitrate leaching were negligible. High potentially mineralizable nitrogen (PMN) in manure and compost plots (Table 4) did not result in greater nitrate leaching than other treatments.

\section{Microbial Biomass Carbon and Potentially Mineralizable Nitrogen}

In all treatments, the concentration of $\mathrm{MBC}$ was higher in the 0 - to $7.5-\mathrm{cm}$ soil depth than in the 7.5- to 15- and 15- to 30-cm depths (Table 4). The PMN was also higher in the $0-$ to $7.5-\mathrm{cm}$ depth than at deeper depths (Table 4). The MBC and PMN concentrations at the 0 -to $7.5-\mathrm{cm}$ soil depth in manure and compost amended plots were higher than those in $\mathrm{N}$-fertilized plots. Generally, the concentrations of MBC and PMN in CTL plots were intermediate between manure or compost and the FRT treatment. Total amount of MBC at the 0 - to $30-\mathrm{cm}$ depth was different among treatments at $P<0.09$ (Table 4). The MBC values of manure and compost plots were higher than the average MBC of the CTL and FRT plots (each was less than $888 \mathrm{~kg} \mathrm{ha}^{-1}$ ). Total amount of PMN in FRT plots was lower than the other treatments.

\section{CONCLUSIONS}

The emissions of $\mathrm{CO}_{2}, \mathrm{CH}_{4}$, and $\mathrm{N}_{2} \mathrm{O}$ at most sampling times were similar among treatments. The large pool of soil total organic $\mathrm{C}$ plus the carbon contribution from plant material (above and below ground) masked the differences (if any) on $\mathrm{CO}_{2}$ emissions due to the residual effects of manure and compost. Most of the $\mathrm{CO}_{2}-\mathrm{C}$ fluxes were from soil microbial and invertebrate activities. Depending on corn growth stage, contribution of root and root-induced respiration to the total $\mathrm{CO}_{2}-\mathrm{C}$

Table 4. The residual effects of compost, manure, and $\mathrm{N}$ fertilizer on concentrations of potentially mineralizable nitrogen (PMN), and soil microbial biomass carbon (MBC) at the 0- to 7.5-, 7.5- to 15-, and 15- to 30-cm depths, and amount of nitrate, PMN, and MBC at the 0- to 30-cm depth on 22 Oct. 1999.

\begin{tabular}{|c|c|c|c|c|c|c|c|c|c|}
\hline \multirow[b]{2}{*}{ Treatment $\dagger$} & \multirow[b]{2}{*}{ Nitrate } & \multicolumn{4}{|c|}{ Soil PMN } & \multicolumn{4}{|c|}{ Soil MBC } \\
\hline & & $0-7.5 \mathrm{~cm}$ & $7.5-15 \mathrm{~cm}$ & $15-30 \mathrm{~cm}$ & $0-30 \mathrm{~cm}$ & $0-7.5 \mathrm{~cm}$ & $7.5-15 \mathrm{~cm}$ & $15-30 \mathrm{~cm}$ & $0-30 \mathrm{~cm}$ \\
\hline & $\mathbf{k g ~ N h a ^ { - 1 }}$ & 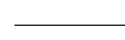 & $\mathbf{m g ~ N ~ k g}{ }^{-1}$ & 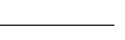 & $\operatorname{kg~Nha^{-1}}$ & 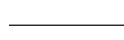 & $\mathrm{mg} \mathrm{C} \mathrm{kg}^{-1}$ & - & $\operatorname{kgC} \mathrm{ha}^{-1}$ \\
\hline CTL & $\mathbf{3 7 . 3 b} \neq$ & $33.5 b c$ & $14.8 \mathrm{bc}$ & 8.1ab & $61.2 \mathrm{a}$ & 86.0ab & $43.2 \mathrm{bc}$ & 49.4ab & $888 b$ \\
\hline FRT & $62.5 \mathrm{a}$ & 23.0c & 11.2c & 6.1b & 43.7b & $58.9 b$ & $32.7 \mathrm{c}$ & $36.5 \mathrm{c}$ & $886 b$ \\
\hline CP1 & 46.4b & 38.6ab & $13.7 \mathrm{c}$ & $8.9 \mathrm{a}$ & $65.5 \mathrm{a}$ & 97.8a & $40.1 \mathrm{bc}$ & 54.1a & 1072a \\
\hline CP2 & $47.3 \mathrm{~b}$ & 42.5ab & 21.7a & $8.3 \mathrm{a}$ & 72.4a & 101.1a & $61.7 a$ & 49.4ab & $1250 a$ \\
\hline MN1 & $47.3 \mathrm{~b}$ & $52.9 \mathrm{a}$ & 18.6a & $6.6 \mathrm{~b}$ & $72.5 a$ & $122.0 \mathrm{a}$ & 52.0ab & $38.5 b c$ & $1191 a$ \\
\hline MN2 & $40.0 \mathrm{~b}$ & 47.5a & 13.8a & $9.0 \mathrm{a}$ & $73.0 \mathrm{a}$ & $120.2 \mathrm{a}$ & $40.0 \mathrm{bc}$ & $54.0 \mathrm{a}$ & $1065 a$ \\
\hline
\end{tabular}

$\dagger$ CTL, control; FRT, synthetic N fertilizer; CP1, compost applied annually; CP2, compost applied biennially; MN1, manure applied annually; MN2, manure applied biennially.

$\$$ Values in the same column followed by different letter are significantly different at $P<0.05$. Values of MBC were different at $P<0.09$. 
fluxes ranged from 10 to $50 \%$ of total $\mathrm{CO}_{2}-\mathrm{C}$ emitted. The $\mathrm{CO}_{2}-\mathrm{C}$ estimated emission was similar to the $\mathrm{C}$ input in the CTL and the FRT plots after seven years of continuous corn production (1992-1998). The fluxes (emissions or uptake) of $\mathrm{CH}_{4}-\mathrm{C}$ were similar to zero $(P=0.05)$, indicating that the residual effects of manure or compost on $\mathrm{CH}_{4}-\mathrm{C}$ emission posed negligible effects on soil $\mathrm{C}$ dynamics and no additional threat to global warming. The fluxes of $\mathrm{N}_{2} \mathrm{O}-\mathrm{N}$ were similar to zero $(P=0.05)$ for most sampling dates, indicating that the residual effect of manure and compost was negligible on $\mathrm{N}_{2} \mathrm{O}$ emission. Compared with $\mathrm{N}$ uptake in corn grain, $\mathrm{N}_{2} \mathrm{O}-\mathrm{N}$ loss was too small to affect the dynamics of soil total N. The residual effects of manure and compost on soil indicators were more favorable than those of the $\mathrm{N}$ fertilizer. The fertilized plots had lower MBC, $\mathrm{PMN}$, and soil $\mathrm{pH}$ compared with the manure and compost plots. In addition to the minimal residual effects of manure and compost on $\mathrm{CO}_{2}-\mathrm{C}, \mathrm{N}_{2} \mathrm{O}-\mathrm{N}$, and $\mathrm{CH}_{4}-\mathrm{C}$ emissions, the residual effects of manure and compost resulted in more favorable soil $\mathrm{C}$ and $\mathrm{N}$ indicators than those of $\mathrm{N}$ fertilizer.

\section{ACKNOWLEDGMENTS}

The efforts of Dr. T.B. Parkin of the USDA-ARS, Ames, IA and Mr. S.L. Arnold of the USDA-ARS, Lincoln, NE in advising and analyzing the greenhouse gases are greatly appreciated.

\section{REFERENCES}

Arnold, S.L., T.B. Parkin, J.W. Doran, B. Eghball, and A. Mosier. 2001. Automated gas sampling system for laboratory analysis of $\mathrm{CH}_{4}$ and $\mathrm{N}_{2} \mathrm{O}$. Commun. Soil Sci. Plant Anal. 32:2795-2807.

Bouman, O.T., D. Curtin, C.A. Campbell, V.O. Biederbeck, and H. Ukrainetz. 1995. Soil acidification from long-term use of anhydrous ammonia. Soil Sci. Soc. Am. J. 59:1488-1494.

Brady, N.C. 1984. The nature and properties of soils. Macmillan Publ., New York.

Bremner, J.M., and A.M. Blackmer. 1978. Nitrous oxide: Emission from soil during nitrification of fertilizer nitrogen. Science 199: 295-296.

Bremner, J.M., G.A. Breitenbeck, and A.M. Blackmer. 1981. Effect of anhydrous ammonia fertilization on emission of nitrous oxide from soils. J. Environ. Qual. 10:77-80.

Bronson, K.F., and A.R. Mosier. 1993. Nitrous oxide emissions and methane consumption in wheat and corn cropped systems. p. 133144. In L.A. Harper et al. (ed.) Agricultural ecosystem effects on trace gases and global climate change. ASA Spec. Publ. 55. ASA, Madison, WI.

Bronson, K.F., A.R. Mosier, and S.R. Bishnoi. 1992. Nitrous oxide emissions in irrigated corn as affected by encapsulated calcium carbide and nitrapyrin. Soil Sci. Soc. Am. J. 56:161-165.

Buyanovsky, G.A., and G.H. Wagner. 1997. Crop residue input to soil organic matter in Sanborn Field. p. 73-84. In E.A. Paul et al. (ed.) Soil organic matter in temperate agroecosystems: Long-term experiments in North America. CRC Press, Boca Raton, FL.

Conrad, R. 1996. Soil microorganisms as controller of atmospheric trace gases $\left(\mathrm{H}_{2}, \mathrm{CO}, \mathrm{CH}_{4}, \mathrm{OCS}, \mathrm{N}_{2} \mathrm{O}\right.$, and $\left.\mathrm{NO}\right)$. Microbiol. Rev. 60:609-640.

Eghball, B. 1999. Liming effects of beef cattle feedlot manure or compost. Commun. Soil Sci. Plant Anal. 30:2563-2570.

Eghball, B., G.D. Binford, and D.D. Baltensperger. 1996. Phosphorus movement and adsorption in a soil receiving long-term manure and fertilizer application. J. Environ. Qual. 25:1339-1343.

Eghball, B., and J.W. Maranville. 1993. Root development and nitro- gen influx of corn genotypes grown under combined drought and nitrogen stresses. Agron. J. 85:147-152.

Eghball, B., and J.F. Power. 1999. Phosphorus and nitrogen-based manure and compost application: Corn production and soil phosphorus. Soil Sci. Soc. Am. J. 63:895-901.

Gajda, A.M., J.W. Doran, T.A. Kettler, B.J. Wienhold, J.L. Pikul, Jr., and C.A. Cambardella. 2001. Soil quality evaluation of alternative and conventional management systems in the Great Plains. p. 381400. In R. Lal, J.M. Kimble, R.F. Follet, and B.A. Stewart (ed.) Assessment methods for soil carbon. Lewis Publ., Boca Raton, FL

Ginting, D., J.F. Moncrief, and S.C. Gupta. 2000. Runoff, solids, and contaminant losses into surface tile inlets draining lacustrine depressions. J. Environ. Qual. 29:551-560.

Hetier, J.M., F. Andreaux, E. Schouller, and C. Marol. 1986. Organic matter inputs to soil after growth of carbon-14-nitrogen-15 labeled maize. Soil Sci. Soc. Am. J. 50:76-80.

Hutchinson, G.L., and A.R. Mosier. 1981. Improved soil cover method for field measurement of nitrous oxide fluxes. Soil Sci. Soc. Am. J. 45:311-316.

Intergovernmental Panel on Climate Change. 1996. Impacts, adaptations and mitigation of climate change: Scientific-technical analysis. p. 745-771. In R.T. Watson et al. (ed.) Climate change: The Intergovernmental Panel on Climate Change. Cambridge Univ. Press, Cambridge.

Islam, K.R., and R.R. Weil. 1998. Microwave irradiation of soil for routine measurement of microbial biomass carbon. Biol. Fertil. Soils 27:408-416.

Kessavalou, A., A.R. Mosier, J.W. Doran, R.A. Drijber, D.J. Lyon, and O. Heinemeyer. 1998. Fluxes of carbon dioxide, nitrous oxide, and methane in grass sod and winter wheat-fallow tillage management. J. Environ. Qual. 27:1094-1104.

Larson, W.E., and F.J. Pierce. 1991. Conservation and enhancement of soil quality. p. 175-203. Evaluation for sustainable land management in developing world. Int. Board for Soil Res. and Management, Bangkok, Thailand.

Lee, G.F., W. Rast, and R.A. Jones. 1978. Eutrophication of water bodies: Insights for an age-old problem. Environ. Sci. Technol. 12:900-908.

Lessard, R., P. Rochette, E.G. Gregorich, E. Pattey, and R.L. Desjardins. 1996. Nitrous oxide fluxes from manure-amended soil under maize. J. Environ. Qual. 25:1371-1377.

Lessard, R., P. Rochette, E. Topp, E. Pattey, R.L. Desjardins, and G. Beaumont. 1994. Methane and carbon dioxide fluxes from poorly drained adjacent cultivated and forest sites. Can. J. Soil Sci. 74: 139-146.

Linn, D.M., and J.W. Doran. 1984. Effect of water-filled pore space on carbon dioxide and nitrous oxide production in tilled and nontilled soils. Soil Sci. Soc. Am. J. 48:1267-1272.

Littell, R.C., G.A. Milliken. W.W. Stroup, and R.D. Wolfinger. 1996. SAS system for mixed models. SAS Inst., Cary, NC.

Lucas, R.E., and M.L. Vitosh. 1978. Soil organic matter dynamics Res. Rep. 358. Michigan State Univ. Agric. Exp. Stn., East Lansing.

Mosier, A.R., D.S. Schimel, W. Valentine, K.F. Bronson, and W.J. Parton. 1991. Methane and nitrous oxide fluxes in native, fertilized, and cultivated grasslands. Nature (London) 350:330-332.

Parkin, T.B., J.W. Doran, and E. Franco-Vizcaino. 1996. Field and laboratory tests of soil respiration. p. 231-245. In J.W. Doran and A.J. Jones (ed.) Methods of assessing soil quality. SSSA Spec. Publ. 49. SSSA, Madison, WI

Qian, J.H., J.W. Doran, K.L. Weier, A.R. Mosier, T.A. Peterson, and J.F. Power. 1997. Soil denitrification and nitrous oxide losses under corn irrigated with high-nitrate groundwater. J. Environ. Qual. 26: $348-360$.

SAS Institute. 1992. SAS/STAT user guide. Version 6, 4th ed., Volume 2. SAS Inst., Cary, NC.

Schepers, J.S., D.D. Francis, and M.T. Thompson. 1989. Simultaneous determination of total $\mathrm{C}$, total $\mathrm{N}$, and ${ }^{15} \mathrm{~N}$ on soil and plant material. Commun. Soil Sci. Plant Anal. 20:949-959.

Sharpley, A.N., T.C. Daniel, J.T. Sims, and D.H. Pote. 1996. Determining environmentally sound phosphorus level. J. Soil Water Conserv. 51(2):160-166.

Smith, J.L., and J.W. Doran. 1996. Measurement and use of pH and electrical conductivity for soil quality analysis. p. 169-185. In J.W. 
Doran and A.J. Jones (ed.) Methods of assessing soil quality. SSSA Spec. Publ. 49. SSSA, Madison, WI.

Sommerfeldt, T.G., and C. Chang. 1985. Changes in soil properties under annual applications of feedlot manure and different tillage practices. Soil Sci. Soc. Am. J. 49:983-987.

Sweeten, J.M., and A.C. Mathers. 1985. Improving soils with livestock manure. J. Soil Water Conserv. 40:206-210.

Wagner-Riddle, C., G.W. Thurtell, G.K. Kidd, E.G. Beauchamp, and R. Sweetman. 1997. Estimates of nitrous oxide emissions from agricultural fields over 28 months. Can. J. Soil Sci. 77:135-144.
Wander, M.M., and S.J. Traina. 1996. Organic matter fractions from organically and conventionally managed soils: II. Characterization of composition. Soil Sci. Soc. Am. J. 60:1087-1094.

Wander, M.M., S.J. Traina, B.R. Stinner, and S.E. Peter. 1994. Organic and conventional management effects on biologically active soil organic matter pools. Soil Sci. Soc. Am. J. 58:1130-1139.

Weier, K.L., J.W. Doran, J.F. Power, and D.T. Walter. 1993. Denitrification and the dinitrogen/nitrous oxide ratio as affected by soil water, available carbon, and nitrate. Soil Sci. Soc. Am. J. 57:66-72. 